\title{
IMAGE MANAGEMENT WITH THE USE OF VIRTUAL COMMUNICATION IN CRISIS SITUATIONS BASED ON THE EXAMPLE OF THE CD PROJEKT CAPITAL GROUP
}

\author{
ZARZĄDZANIE WIZERUNKIEM Z WYKORZYSTANIEM KOMUNIKACJI WIRTUALNEJ \\ W SYTUACJACH KRYZYSOWYCH NA PRZYKŁADZIE GRUPY KAPITAŁOWEJ CD PROJEKT
}

\author{
Mateusz Pacierz \\ Jan Kochanowski University of Kielce \\ Stefana Żeromskiego Street 5, 25-369 Kielce \\ mateuszpacierz@poczta.pl 0 ORCID 0000-0002-8382-5440 \\ DOl: 10.2478/minib-2021-0012
}

\section{ABSTRACT}

Image management in crisis situations is one of the most important functions, not only for a company's team responsible for marketing, but also for its executives and strategists. Given today's ubiquity of the Internet, crises spread faster than just a few years ago, making it important to halt them effectively with the help of virtual communication. This article first considers the theoretical fundamentals in the field of image management, defining the concept of crisis, its sources and phases. Next, the empirical part presents a profile of the company under consideration, CD Projekt, examining selected examples of the crisis situations in has experienced. We then describe the solutions and strategies the company undertook to minimize the effects of the crisis, mainly losses of reputation. A survey was also carried out on a sample of 354 people from the company's broader environment in order to gauge people's opinions about changes in the company's perception.

Key words: image management, public relations, marketing, crisis 


\section{ABSTRAKT}

Zarządzanie wizerunkiem w sytuacjach kryzysowych jest jedną z najważniejszych funkcji nie tylko zespołu odpowiedzialnego za marketing, ale również menedżerów i osób strategicznych. Powszechność internetu sprawia, że kryzysy rozszerzają się szybciej niż jeszcze kilka lat temu, dlatego istotne jest, aby równie skutecznie je hamować właśnie przy pomocy komunikacji wirtualnej. W artykule zawarto teoretyczne podstawy z zakresu zarządzania wizerunkiem oraz zdefiniowano pojęcie kryzysu, jego źródła i fazy. W części empirycznej został przedstawiony profil badanego podmiotu oraz wybrane przykłady sytuacji kryzysowych w których się on znalazł. W pracy zostały opisane rozwiązania i strategie, jakie podjęła spółka w celu minimalizacji efektów kryzysu, gtównie strat wizerunkowych. Zostały także przeprowadzone badania na próbie 354 osób ze środowiska organizacji w celu poznania opinii dotyczącej zmian w postrzeganiu studia.

Słowa kluczowe: zarządzanie wizerunkiem, public relations, marketing, kryzys

JEL: : M12, M31, M54

\section{Introduction}

In these times of universal access to media and instant information circulation, maintaining a good reputation or image has become one of the most important issues in many aspects of life. The success of a project hinges to a large extent on how it is perceived by the environment - be it introducing a new product to the market, waging a political campaign or attempting to establish cooperation. This is the main reason why so many company resources are currently being allocated to departments responsible for image management. This is fully justified, given the risk that such a crisis can entail.

These days crisis situations are much worse for representatives of given industries than just a few years ago, because the news about troubles 
travels very quickly, and public trust or a good reputation, once lost, are much more difficult to regain. Today, having a "plan B" as a limited strategy in the event of unforeseen situations is not enough - rather, one needs to know how to quickly and effectively avert the danger and be able to actually do so. This means having a good command of all channels that can almost instantly allow for the maximum reduction of negative consequences and complications. Public Relations specialists make use of various methods in crisis situations, but the fastest and immediate effect can nowadays be achieved with Internet communication. Tools such as programs, portals and applications give entities a chance to emerge virtually unscathed even from the most difficult moments, and often bring them even more benefits than losses. The Internet, however, should be treated as a double-edged sword - what yields a positive effect today may lead to a tragic end tomorrow. A strategy that works excellently for small businesses might be disastrous for large corporations. The powerful marketing weapon of virtual communication should be treated with due caution, because if used in an inconsistent way, it may be counterproductive (Helman, 2014).

The present paper, after first reviewing the literature on company image management, crisis management, and public relations, examines the case of the Polish computer game studio CD Projekt, which has been on quite a whirlwind ride in terms of $\mathrm{PR}$ over the last 2 years. We analyze the actions taken by CD Projekt in 2020-2021 and its approach to various crisis situations, especially examining the organization's Internet messaging. We describe the solutions and strategies the company undertook to minimize the effects of the crisis, mainly losses of reputation. The most significant events in the company's media environment are analyzed, selected on the basis of the greatest total number of reactions, comments and articles related to the given events. These examples are juxtaposed against the corresponding strategies and concepts from the literature. Attention is also paid to factors such as stock prices and prestigious rankings, which sometimes offer evidence in support of the claims made in the analysis. Next, we report the results of a survey carried out on a sample of 354 individuals among the broader environment of the company's stakeholders, in order to gauge people's opinions about changes in the company's perception, and then present some conclusions. 


\section{Theoretical aspects and literature review}

Before considering specific events, let us first review some of the theoretical fundamentals of crisis management. The word "crisis" in its original meaning has been defined as "a period of breakdown, a turning point, or a potential breakthrough in the functioning of a given social or political system" (Kaczmarek-Śliwińska, 2015). This statement is quite broad and general, whereas the "crises" described by the literature on specific industries are much narrower and more detailed. A crisis at an organization, which is the subject of research in this article, has been described by Barton as "a major unpredictable event that has potentially negative results. The event and its aftermath may significantly damage an organization and its employees, products, services, financial condition and reputation" (Barton, 1993). Lesly, on the other hand, highlights the role of crisis as a determinant of future actions and decisions. In his opinion, a crisis is "a major turning point resulting in permanent drastic change. If is far more critical than most issues or emergencies. Crises are of great importance, but they are rare" (cited after Coombs, 2011). In terms of frequency, situations of "crisis" status occur quite rarely and rather irregularly. Considering the crisis phenomenon from the aspect of an organization's image, it brings about consequences that are magnified by the degree of interest it attracts from the company's environment such conditions may constitute a potential risk factor in the future (Falecki, 2013). Summarizing the various accounts cited above, we can identify certain features and fragments that generally characterize the crisis process in an organization, which include:

- Disruption in the normal course of business;

- Financial or reputational risk;

- Involuntarily arousing interest from the environment;

- Changes in the organization;

- Need for a quick response;

- Suddenness of occurrence. 
The various phases that a crisis may proceed through are summed up in Table 1.

\section{Table 1. Breakdown of a crisis situation into phases}

\begin{tabular}{l|l}
\hline Pre-crisis phase & $\begin{array}{l}\text { As a rule, already at this stage there are indications of a possible crisis. If the crisis } \\
\text { team makes the right decisions quickly enough, it is possible to avoid further } \\
\text { development of the problem. Any signs of an impending crisis should not be } \\
\text { underestimated, as managing it at this stage costs less resources than in subsequent } \\
\text { phases. }\end{array}$ \\
\hline Strong crisis phase & $\begin{array}{l}\text { A lack of reaction or incorrect decisions made by the company in the previous phase } \\
\text { result in a strong crisis phase. This step only helps to limit the damage - it is too late } \\
\text { for preventive measures. The effects of this phase are felt for the company in a } \\
\text { relatively short time. }\end{array}$ \\
\hline Chronic crisis phase & $\begin{array}{l}\text { At the stage of the chronic crisis, the organization has already completed the period } \\
\text { of quick decisions and actions to "put out the fire". A certain stability and the ability } \\
\text { to control the crisis allows its causes to be identified and corrective actions to be } \\
\text { carried out in the long run. }\end{array}$ \\
\hline Crisis resolution stage & $\begin{array}{l}\text { The final stage of resolving the crisis involves drawing the appropriate conclusions, } \\
\text { because without doing so, the organization will continue in the previous stage. Correct } \\
\text { analysis allows the company to be protected against such events in the future. }\end{array}$ \\
\hline
\end{tabular}

(based on Fink 1986 and Surowicz 2011)

Crisis management is considered an element of strategic management in enterprises, which embraces actions and decisions not only during a crisis situation, but also before and after the event (Surowicz, 2011). Crisis management efforts strive to maximally reduce risk and uncertainty, as well as to control of the course of a crisis situation. In practice, this includes all operations undertaken by the team that are aimed at maintaining a favorable image of the company despite negative events related to it in some way. It should be noted that it is not uncommon to for negative effects to affect an entire industry, triggered by a crisis on the part of one of its participants. Crisis management is also included in socalled "business continuity planning", which is designed to prepare comprehensive operational activities that must be performed for the company to function properly (as in the pre-crisis state) (Fulmer, 2007). 
The most important task in this concept is to maintain the critical functions of the organization so that it is able to keep running continuously.

\section{Table 2. Crisis-generating factors}

\begin{tabular}{|c|c|}
\hline Internal factors & External factors \\
\hline $\begin{array}{l}\text { - Incorrect decisions made by managers } \\
\text { - Faulty actions taken by employees } \\
\text { - Lack of operating procedures } \\
\text { - Incorrect financial policy of the organization } \\
\text { - Incorrect division or lack of competences within the } \\
\text { organization } \\
\text { - Controversial brand-related actions }\end{array}$ & $\begin{array}{l}\text { - Vendor factors } \\
\text { - Actions by political or public authorities } \\
\text { - Company-environment factors (suppliers; distribution, } \\
\text { etc.) } \\
\text { - Competitor actions (intentional or not) } \\
\text { - Unforeseen events (natural disasters, acts of terrorism, } \\
\text { etc.) } \\
\text { - Ecology } \\
\text { - Changes in the societal environment (technology/ } \\
\text { ulture/customs) } \\
\text { - Media development - rivalry, rumors, etc. }\end{array}$ \\
\hline
\end{tabular}

(based on Surowicz 2011)

The various sources of crisis situations are summed up in Table 2 . The sources listed there may of course be interrelated - almost never is a crisis composed of only one factor. It sometimes happens that a given crisis factor is only the source of further problems that begin to accumulate in an uncontrolled way (Michalik, 2004).

Crisis management, apart from knowledge, strategies and a background of theoretical information, also requires tools to apply them in a practical way. Currently, these primarily include the organization's own media channels, through which it can reach out to its recipients. Such media support is not only useful at the time of intervention in the face of an active crisis, but also after its end or even as part of preventive actions (Rydzak, 2007). In order to be able to harness the potential of such media channels to the maximum, specific tasks may be assigned to each channel (in the context of crisis situations), the performance of which in the specific conditions of a given medium will bring the best results. Crisis management processes offer some real reflection of how a brand builds its image. This is especially true in the Internet environment, where any 
attempts to change or turn back from the paths chosen by the company are immediately verified by observers, journalists or customers. A company's image reflects how it is perceived by its surroundings - it can be described as the result of subjective assessments by other market entities (Chmielewski, Tworzydło, Ochmański, 2012).

Therefore, the basis for maintaining a coherent and beneficial "portrait" of an organization lies in preparing a crisis management procedure in line with the company's long-term policy. When preparing such a procedure, attention should be paid to the aforementioned stages (pre-crisis, crisis, post-crisis), which will determine the measures and actions taken (Tworzydło, 2017). The more prepared the crisis management team is before a crisis occurs, the less serious its consequences will be. Preparation is also the stage that requires the most "abstract" work. The team is prepared under certain specific assumptions that do not necessarily have to actually occur, but some mechanisms will remain the same for most problems, which allows for shorter reaction times (Tworzydło, 2019).

\section{Projekt - A Profile}

The computer game studio CD Projekt was set up by Marcin Iwiński and Michał Kiciński in 2002, although these two founders of Poland's computer games industry had already been active a decade earlier. The market activity of CD Projekt has truly followed a "from rags to a riches" path, from selling games imported from abroad at outdoor computer fairs in Warsaw all the way to launching a new development team in Canada. Favorable economic conditions (the political changes in 1989, economic development, high market demand) and many innovative decisions on a national scale have allowed the company to become one of the leaders in the Polish video game market. This success was largely due to the series of computer games from the "The Witcher" series, based on the motifs of Andrzej Sapkowski's fantasy books. The last part of the trilogy, with the subtitle "Wild Hunt", brought the studio over 300 awards and sold over 30 million copies worldwide, bringing the overall total of copies of the series of games about the valiant Geralt's adventures to 50 million (Gram.pl, $22 / 04 / 2021)$. 
The studio's continued successes resulted in the appearance of the CD Projekt capital group on the Warsaw Stock Exchange. However, the company was not initially sought after by investors, with fluctuations in the prices around 21.22 PLN per share remaining minimal — until the release of the 2 nd expansion pack for the game "The Witcher 3 ", when the shares began to gradually rise. The financial success of the studio's first independent production allowed for the commencement of work on another game, set on a futuristic Earth. "Cyberpunk 2077" (CP2077) was officially announced at the 2018 trade fair. This production became a turning point for the company's stock quotations. Several aspects have contributed to strong interest among the community:

1. CD Projekt created a highly recognizable brand in the gaming world as well as in culture. Modern solutions, player orientation, a strong emphasis on storytelling in its games and interesting references to pop culture - these are just a few factors behind the studio's success.

2. A comprehensive and global marketing strategy - the company put a lot of emphasis on diverse and engaging forms of advertising and promoting ira games, which translated into a strong interest in their latest production. The studio cooperated with such companies as Coca Cola, Sony, Adidas and Porsche.

3. Precise target groups and accurate demand research - the series of The Witcher games was very well received in Poland and other Slavic countries due to numerous references to the Slavic culture. Cyberpunk 2077 , in turn, was a response to the growing interest in science fiction and to the ambiance of the 1980 s returning to fashion.

Regular fresh news about the game and the development of the studio, promotional campaigns and cooperation with many partners contributed to a significant increase in the value of the company's shares, which culminated in December 2020, reaching 464.20 PLN per share. Prior to then, any significant price drops were mainly dictated by shifts in release dates, but starting in the fall of 2020, the mood gradually began to decline, despite the game's successes even before its release (Gry-online.pl, 2020a). A serious crisis began for the CD Projekt group in December, during the time of its major premiere of Cyberpunk 2077. 
Chart 1. CD Projekt shares on the Warsaw Stock Exchange

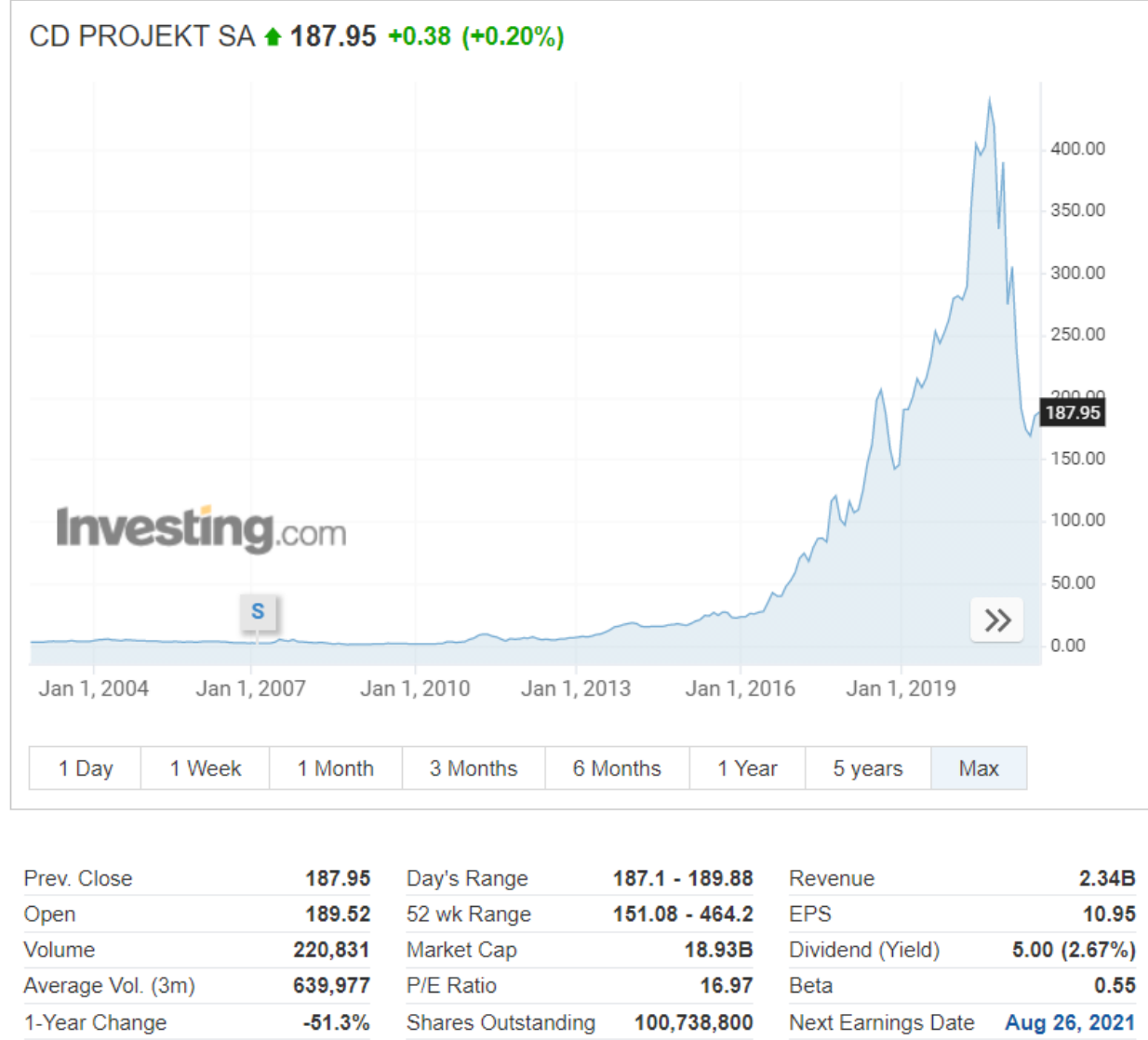

(from investing.com, 2021)

\section{Crisis situations and remedial actions by CD Projekt in 2020-2021}

\section{A. Continually receding release date}

The vast majority of the studio's image problems were generated by internal bad organizational decisions. Initially, the product was slated to be released in April 2020, but in January it was postponed for the first time to 17 September 2020. The vast majority of the community received this 
information with understanding, counting on a better gaming experience at the cost of waiting a few more months. However, the situation became worrying when in June, amidst a very "hot" period from the marketing point of view, the company announced another pushback of the release date to 19 November 2020. Among the community of players and journalists, uncomfortable questions and comments began to appear, the common denominator of which was doubt about whether the actual state of production complied with the assurances of the creators. However, the real "straw that broke the camel's back" came in October, when there was a third postponement, this time by a further 21 days. Thousands of players once again felt led town by the company. There was anger, irritation and mockery, which were expressed in comments on the manufacturer's website and on industry press websites. Memes (pictures intended to comment on reality in a funny way) dealing with Cyberpunk began to circulate on the web - in a normal situation this could be a useful phenomenon, but at the time of a marketing "fire" they came as additional "fuel" for it.

The post, in Polish, contains the announcement of the 21-day postponement as well as some attempts at justification and offering reassurances about the state of the game's development. Large numbers of Facebook users reacted to the letter with sarcasm and ridicule, as is evident on the image shown here in the numbers of "thumbs-up" "tear-shedding" and "laughter" reactions that the letter signed by representatives of the CD Projekt management board received. In the comments section, the community was divided, and a hate-fest and attacks against those responsible for this state of affairs intensified.

While postponing the deadlines by practically 9 months, the studio continually had to adopt defensive strategies. Its messages published primarily on the Internet bore the characteristics of a "genuine apology" strategy. This type of strategy is adopted in a situation where the fault is entirely on the side of the organization, the crisis being solely the result of its incorrect decisions. Similar phrases appeared in subsequent statements, which somewhat softened the dispute between the players and the studio. PR specialists tried to distract the audience with engaging materials that appeared on the developer's channels. 
Announcements about elements of the soundtrack, technical innovations or high-profile collaborations, apart from promoting the game, could be treated as attempts to cover up unfavorable comments and negative attitude. In all, these efforts contributed to the sale of 8 million pre-orders of the game prior to its release - a result that should be treated as a great success for the company, and therefore for the team responsible for projecting its image (CD-Action.pl, December 2020).

\section{B. 6-day working week}

In corporate language, a "crunch" is a time of very hard work, forced overtime, usually shortly before the deadline for completing an important task. Three months prior to the Cyberpunk premiere, official information appeared on the web about compulsory crunch at the company - about the working week at CD Projekt being extended to 6 working days for the majority of employees. Disgust in the gaming environment was all the greater that a year earlier, in one of the interviews, the CEO of the studio declared that he'd take action to avoid such a crunch time. Thus yet another promise was broken in a short time, despite quite attractive financial conditions being promised to employees in exchange (additional earnings + bonus from the company's profit in 2020).

This time, the CD Projekt executives in their statement adopted a justification strategy, the application of which is associated with relatively small losses caused by the crisis. Strengthening the message of the issue of financial benefits for the "victims" of the decision and drawing attention to the desire to ensure fulfillment of another promise (meeting the premiere on time) contributed to the justification, which was accepted by some of the community, although it continued to cast a bad light on the working culture at the company (Spidersweb.pl, 2020). 
Fig 2. A message from a top management member regarding crunch on Twitter

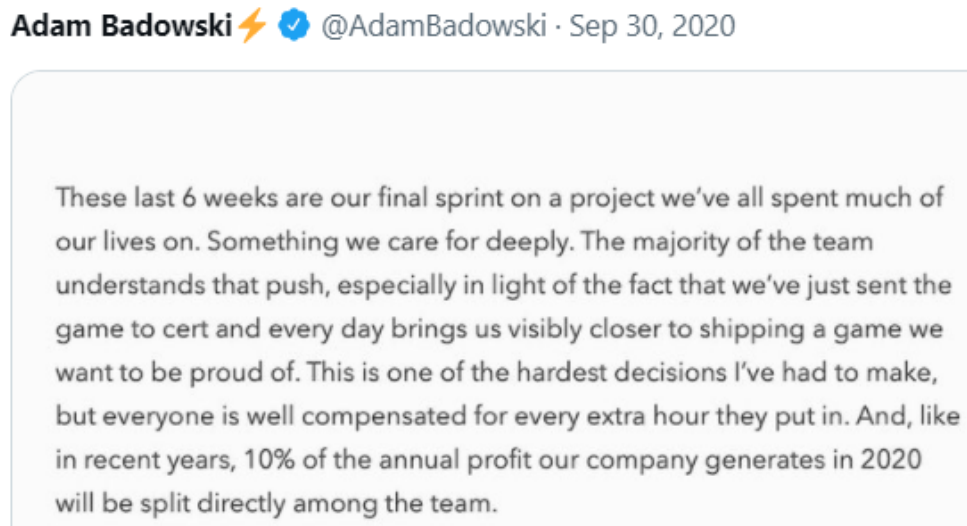

(3) Jason Schreier $\$$ @jasonschreier·Sep 29, 2020

Last year, the bosses of CD Projekt Red approached me for an interview. They wanted to announce that for Cyberpunk 2077, they would be avoiding mandatory crunch.

This week, they sent out an email to staff announcing studio-wide ... Show this thread
Q 736
七】 $2.1 \mathrm{~K}$
O $9.2 \mathrm{~K}$
个

(Twitter.com, July 2021)

\section{Bad PR of the company's own making: criticism of the company after the release of CP2077}

Cyberpunk was a project that the studio had worked on for 8 years until its premiere. In the end, this proved to be too short a period, because after the game's release, it turned out to be full of technological flaws, known as bugs or glitches in programming jargon. No wonder, then, that the disappointment felt by thousands of players was almost in proportion to the time that had been spent creating the game. All the bad decisions that were made at the company (especially in 2020) found their consequences in the 
first few weeks. The most unfavorable phenomena for CD Projekt at that time are described in the Table 3.

\section{Table 3. Occurrences negative for CD Projekt in the winter of 2020/2021}

\begin{tabular}{|c|c|}
\hline Date & Description of the situation \\
\hline 10.12 .2020 & $\begin{array}{l}\text { The premiere of the game is massively celebrated, the product breaks new records at an express } \\
\text { pace, initially the community is delighted. The first mentions of numerous errors and failures } \\
\text { appear, despite the optimism of players, Cyberpunk gathers at best "good" reviews. }\end{array}$ \\
\hline 12.12 .2020 & $\begin{array}{l}\text { Large numbers of players note the glaring problems in the game, once again feeling cheated. } \\
\text { The project starts to garner the worst reviews, especially for the console versions. }\end{array}$ \\
\hline 13.12.2020 & Shares in the CD Projekt group on the stock exchange start to exhibit a gradual decline. \\
\hline 16.12 .2020 & $\begin{array}{l}\text { The product loses the prestigious Metacritic seal of approval, due to thousands of negative } \\
\text { reviews. }\end{array}$ \\
\hline 18.12.2020 & $\begin{array}{l}\text { Cyberpunk is removed from PlayStation Store, which allows console owners to purchase the } \\
\text { game. The reason cited for this decision was its "deplorable technical condition". This deals } \\
\text { a huge blow to the Polish company's image, translating into a sharp weakening on the stock } \\
\text { exchange. On } 18 \text { December, the price of one share was } 264 \text { PLN, which means that the company } \\
\text { lost over } 200 \text { PLN per share within } 2 \text { weeks. }\end{array}$ \\
\hline 19.12.2020 & $\begin{array}{l}\text { Information is circulated about quarrels during internal talks at the company. People working } \\
\text { on the game accuse the management of lies and hypocrisy. }\end{array}$ \\
\hline 20.12.2020 & $\begin{array}{l}\text { The law firm Wolf Haldenstein Adler Freeman \& Herz LLP prepares a class action lawsuit } \\
\text { against the studio. }\end{array}$ \\
\hline 10.01.2021 & $\begin{array}{l}\text { The Polish Office of Competition and Consumer Protection (UOKiK) carries out an inspection } \\
\text { at the company, concerning product improvement and the handling of returns. }\end{array}$ \\
\hline
\end{tabular}

The company's negligence made successive problems an almost natural process. At times, the atmosphere was close to that of a scandal, which is why the period of late 2020 and early 2021 was not much easier for the group than in the previous months. CD Projekt executives had to look for new solutions so that long years of work would not go to waste. At the beginning of probably the greatest crisis in the company's history, the management board had to apologize once again and admit to having made 
mistakes. The first step in regaining the trust of its customers was for the studio to allow product returns directly through their platform. This approach did not diminish customer anger, but it did somewhat suppress their anguish and demonstrated the company's good intentions despite its failure. Some players expressed their approval for this approach, claiming that despite exercising their right of return, they would support developers in repairing the product. Being in a losing position, CD Projekt decided to focus on honesty: customers would not be lied to once again, so this approach definitely had a positive impact on contact with contractors. The satisfied portion of customers showed special support, which in turn allowed the studio to base its rhetoric on the "coaxing" strategy. This concept is effective in situations where the organization has a good reputation and a crisis of this scale is very rare for them.

Another statement made by Adam Badowski, who referred to the alleged "employee rebellion" regarding the management's lies about the state of the game on the day of the premiere, helped a lot in cleaning up the situation. The head of the studio firmly denied some of the allegations, which is a good tactic in the case of information based on gossip or slander. People following the development of the situation pointed out Badowski's failure to addresss the remaining accusations, concerning unrealistic deadlines and other issues. Nevertheless, the post received 6,000 positive reactions.

Unfortunately, no statements or announcements were able to definitively end the crisis. With problems on such a large scale, it was necessary to undertake a strategy of remedial action. In practice, this meant changing not only communication plans, but also operational ones. The announcement of that the game would be fixed was made a few days after the premiere, but the subsequent effects in the form of a sharp drop in the stock listing, agitation among investors and the generally negative image of the Polish company forced the studio to take additional measures.

The response came in the form of a statement by Marcin Iwiński on 14 January 2021. The CD Projekt co-founder once again asked the players to accept an apology, revealing the behind-the-scenes story of pre-release work on the game. More positive news emerged later in the statement. The most important element of the video published on the web was the presentation of the Cyberpunk recovery plan. This time, the producers 
opted not to give specific dates, but instead named approximate periods for subsequent updates. Iwiński presented on the timeline the assumed schedule of hotfixes and announced the release of free DLCs to the game. Owners of new generation consoles could be pleased with this, as they would receive an update patch for free, which is not a standard in the gaming industry. In his statement, the company's co-founder also referred to similar situations with previous productions, which may have somehow reassured players. Ultimately, Iwiński's film received 270,000 positive reactions on YouTube.

To date, CD Projekt has not finally rid itself of its problems, but the change in management approach, taking a very effective and honest approach to marketing and image building, has created a certain chance for a positive conclusion to this story.

\section{Opinion of the environment on image changes}

To gain further insight into the impact of CD Projekt's efforts to salvage or improve its image, we carried out a questionnaire survey among individuals in the gaming community or broader environment of stakeholders. The survey was made available on various thematic groups from the computer game industry, and in industry and investor media. Over 354 people voluntarily participated in the study. Of these, over 60\% were aged up to 24 years old, about $22 \%$ were aged $25-30$, and less than $15 \%$ were over 30 . About $80 \%$ of respondents said they were interested in the Polish company's fate because they identified as a member of the gaming community. The remaining $20 \%$ of the respondents were divided into persons interested in the company due to the profile of their work or from the standpoint of stock exchange investments. On a 5-point scale, the vast majority (almost $70 \%$ of responses) of the respondents assessed the company's image before the premiere of Cyberpunk 2077 at a rating of 5 . Another $23 \%$ gave a rating of 4 , which in total means over $93 \%$ of votes positively evaluating the brand's earlier image.

The sample was much more divided on the question regarding the evaluation of the efforts to fix the game. The dominant rating was 3 (over $40 \%)$, meaning the view that "correct action" was taken, while the 
remaining answers were divided almost symmetrically — over $24 \%$ of respondents gave a rating of 2 or 4 , the lowest rating of 1 was chosen by approx. $8 \%$, while less than $4 \%$ gave 5 , or "very good".

\section{Chart 2. Answers to the survey question regarding assessments of the CP2077 remedial action}

\section{How do you rate the actions to improve the situation of Cyberpunk 2077?}

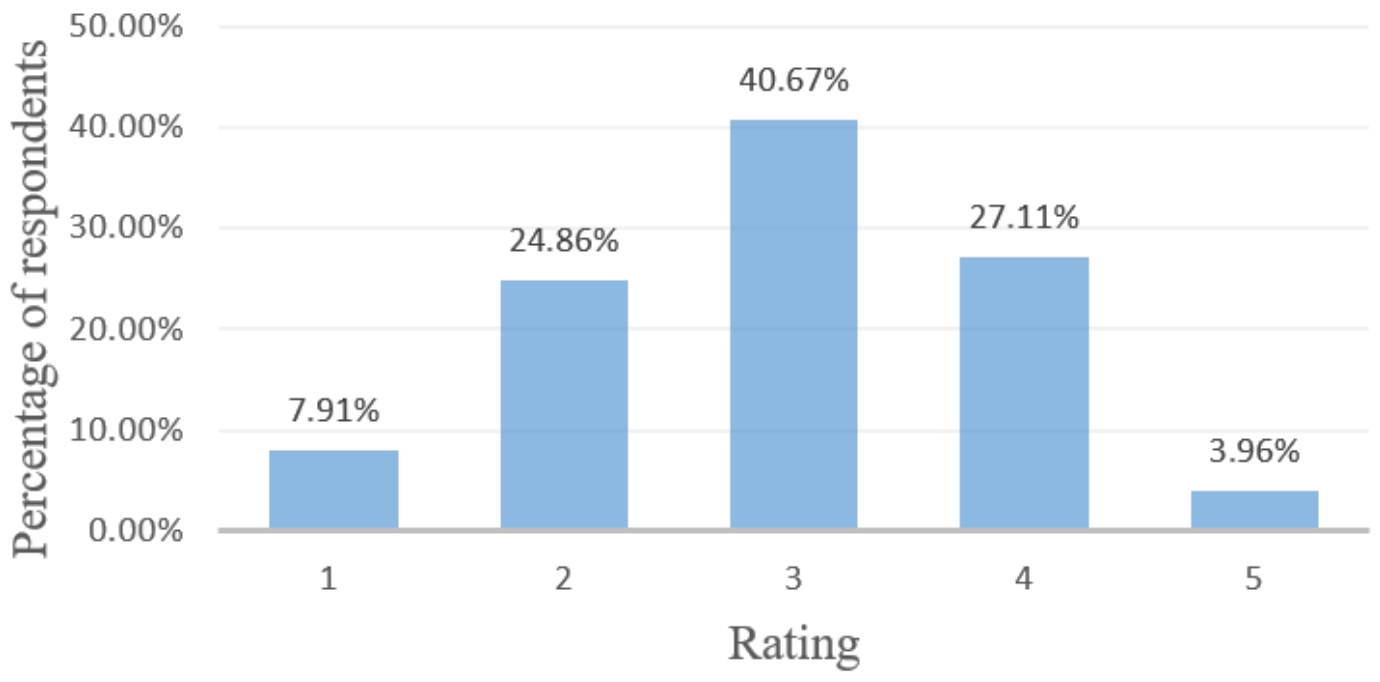

The questionnaire also included a question addressed strictly to investors, asking for opinions on the credibility of CD Projekt as a partner or investment target in the stock market. Among respondents who answered this question, less than $17 \%$ said that they had lost confidence in the studio, $24 \%$ felt that the brand was still trustworthy, while more than half said this still depended on the developers' subsequent actions. It can therefore be concluded that this exploratory test of the investor community seems to indicate that people have become more cautious in contact with the company.

Such a partial loss of trust may also be evidenced by the responses to the penultimate question. As many as $63 \%$ of respondents admitted that after such a situation they would not decide to pre-order a game ever in the 
future, $22 \%$ would continue to do so in the case of AAA games, while others were not sure of their decision. This is a good example that a crisis a one company in an industry may cause ripple effects to the business of other market entities.

As of 1 July 2021, CD Projekt started to emerge from the crisis of the previous winter. A new quality in the approach to the customer, less aggressive marketing and attempts at displaying the company's best side have yielded tangible results. The promised updates were released as scheduled, and the game returned to the Playstation Store on June 21. Players appreciated the efforts of the developers, because within 9 days of CP2077's return to the store for people with a console, it gained the status of the "game of the month", ahead of other very popular productions. FandomSpot research has shown that Cyberpunk has the 6th largest community on the web. Moderate optimism is also confirmed by the distribution of responses to the final question on the questionnaire, concerning the opinions of the respondents on the current image of CD Projekt.

\section{Chart 3. Assessment of the studio's image by the respondents (as of July 2021)}

\section{How do you rate the overall image of the CD Projekt studio at the moment?}

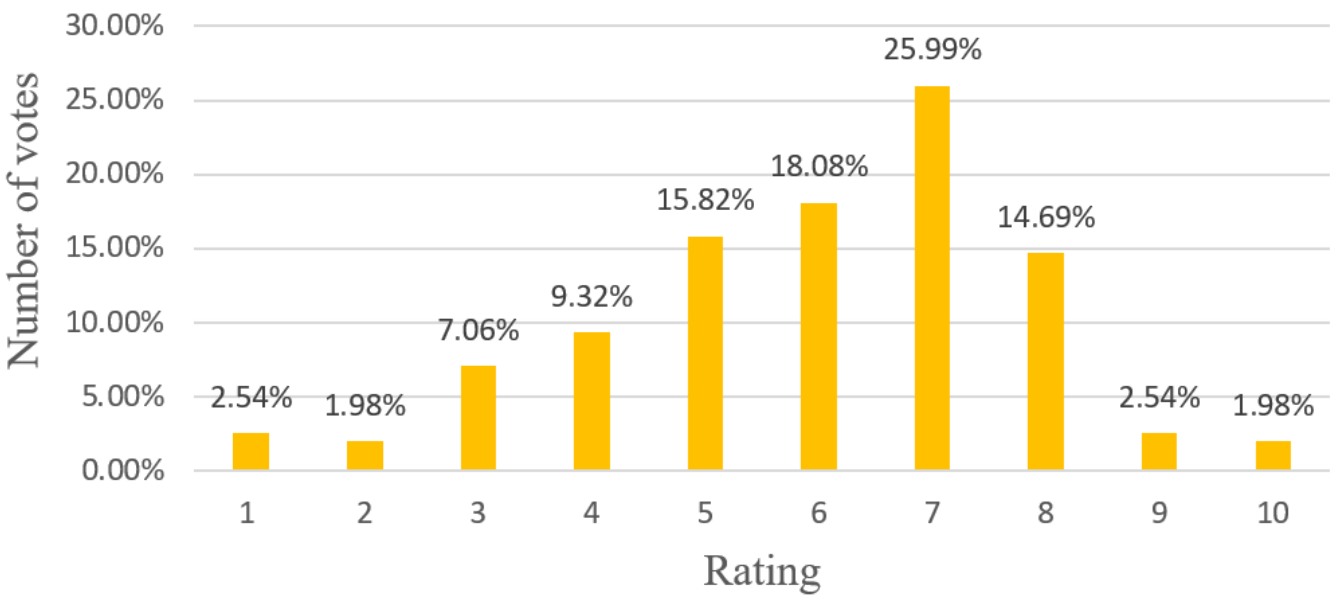

The results show that the current perception of the studio by the environment is not as exemplary as it seems to have been back in 2020 . 
Nevertheless, executive efforts focused on fighting for the client and appropriate targeting of marketing activities have allowed the company to maintain a certain level of trust, which is still quite high given the number of crises the company underwent in the period in question.

\section{Summary}

Investing in crisis management is often likened to buying an insurance policy - certain resources are allocated to it, without knowing if it will ever prove useful. However, as shown by the example of the CD Projekt group, it is better to future plans to make contingencies for strategies in the event of failure, both external and internal. The lack of any concept for how to rescue the company's image in the face of potential threats may in just a short time cause the company to lose everything it has worked for, for so long. The example of the gaming industry demonstrates the great importance of marketing based on long-term prospects and including virtual communication in it. Dialogue between an organization and its broader community on the Internet can quickly bring great popularity, but also huge losses. The examples cited in the empirical part prove that it is enough, however, to take care of a few important elements in the message that will allow you to build a healthy relationship with the environment and maintain a good image. First, the speed of reaction and taking action are important - the more swift the response to a crisis, the lower the risk of its further development. Another issue is taking an honest and truthful approach to recipients - an exposed lie or fraud will plunge the company into an even deeper crisis. The messages that are communicated should be official from the outset, and their language should be simple and understandable, so that there is no room for misunderstandings or distortions. In the moment of a crisis, the actions taken by the company should be coordinated and consistent, so that in the event of subsequent problems it doesn't turn out that there are different versions of this event (recipients in such a moment very quickly and often lose their trust irretrievably). The last element, which was also noticeable in CD Projekt's messages, was the selection of appropriate people for the statements made. If criticism falls on any element of the company, the board member or 
appointed representative should speak first. Following these few rules is a good starting point to end the crisis and defend your image to some extent. The examples described in the work show that mutual respect and an honest approach to the client will always defend themselves, if only you don't make big mistakes along the way and use the appropriate techniques.

\section{Bibliography}

1. Barton, R. (1993). Crisis Management, Oxford: Oxford University Press, 12.

2. cdaction.pl (2021). Preordery wystarczyty, by zwrócity się koszty produkcji i marketingu. https:/www.cdaction.pl/news-62653/cyberpunk-2077-preordery-wystarczyly-byzwrocily-sie-koszty-produkcji-i-marketingu-gry.html (01.07.2021).

3. cdprojekt.com (2021). Historia CD Projekt. https://www.cdprojekt.com/pl/grupakapitalowa/historia/ (01.07.2021).

4. Chmielewski, Z., Ochmański, H., Tworzydło, D. (2012). Budowanie wizerunku w sieci możliwości i zagrożenia [Image Building Online: Opportunities and Threats]. Marketing of Scientific and Research Institutions, 4(225), 321-326.

5. Coombs, W. T. (2011). The Handbook of Crisis Communication. Chichester, UK: John Wiley, 266.

6. Dzierżyńska-Mielczarek, J. (2018). Rynek mediów w Polsce. Zmiany pod wptywem nowych technologii cyfrowych [The Media Market in Poland: Changes Under the Influence of New Digital Technologies]. Warsaw: Oficyna Wydawnicza ASPRA-JR.

7. Falecki, J. (2013). Zarzadzanie kryzysowe $w$ teorii $i$ praktyce [Crisis Management in Theory and Practice], Part 1. Kielce: Wyższa Szkoła Handlowa im. Bolesława Markowskiego w Kielcach.

8. Fink, S. (1986). Crisis Management: Planning for the Inevitable. New York: Amacon.

9. Fulmer, K. L. (2007). Business Continuity Planning: A Step-by-Step Guide with Planning Forms. Brookfield: Rothstein Publishing.

10. gry-online.pl (2020a). Świat reaguje na przesunięcie premiery. https:/www.gryonline.pl/newsroom/cyberpunk-2077-swiat-reaguje-na-przesuniecie-premiery/z81e011 (01.07.2021)

11. gry-online.pl (2020b). Patch 1.23 zbiera pochwaty za optymalizacje. https://www.gryonline.pl/newsroom/cyberpunk-2077-na-ps4-patch-123-zbiera-pochwaly-zaoptymalizacje/za1ff7f (04.07.2021).

12. Helman, B. (2014). Zaangażowanie w wideo [Video Engagement]. Marketing w Praktyce, $3,45-46$.

13. investing.com (2021). CD Projekt shares on the Warsaw Stock Exchange. https://pl.investing.com/equities/cdproject (02.07.2021)

14. Kaczmarek-Śliwińska, M. (2015). Public Relations $w$ zarządzaniu sytuacjami kryzysowymi organizacji. Sztuka komunikowania się [Public Relations in the Management of Crisis Situations in the Organization: The Art of Communication]. Warsaw: Difin. 
15. Michalik, M. (2004). Zarządzanie sytuacjami kryzysowymi [Managing Crisis Situations]. in H. Mruk (Ed.), Komunikowanie się $w$ marketingu. Warsaw: Polskie Wydawnictwo Ekonomiczne.

16. Polish Stock Exchange (2021). https://www.gpw.pl/spolka?isin=PLOPTTC00011 \#quotationsTab (1.01.2021).

17. Rydzak, W. (2007). Zarządzanie informacją w sytuacjach kryzysowych [Information Management in Crisis Situations]. In J. Olędzki, D. Tworzydło (Eds.), Public relations. Znaczenie społeczne $i$ kierunki rozwoju. Warsaw: Wyższa Szkoła Informatyki i Zarządzania w Rzeszowie.

18. spidersweb.pl (2021). Będa pracować 6 dni w tygodniu, żeby dowieźć na czas Cyberpunka 2077. https://spidersweb.pl/2020/09/cd-projekt-red-crunch-cyberpunk-2077.html (1.07.2021).

19. Surowicz, A. (2011). Zarządzanie marką w sytuacji kryzysowej [Brand Management in a Crisis Situation]. In M. K. Witek-Hajduk (red.), Zarzqdzane silna marka. Warsaw: Wolters Cluwer.

20. Tworzydło, D. (2017). Procedura zarządzania w kryzysie wizerunkowym w mediach przeciwdziałanie, reagowanie oraz odzyskiwanie utraconych korzyści [The Procedure of Management in an Image Crisisin the Media - Counteraction, Reaction, and Regaining Lost Benefits]. Studia Medioznawcze, 3(70), 78-81.

21. Tworzydło, D. (2019). Zarzadzanie $w$ kryzysie wizerunkowym. Metody, procedury, reagowanie [Managiement in an Image Crisis: Methods, Procedures, Reaction], Warsaw: Difin.

Mateusz Pacierz, Jan Kochanowski University in Kielce, Faculty of Law and Social Sciences, Institute of Management - a student of Management with a specialization in Trade and Exhibition, president of the Students Science Club "Lider". His interests include modern techniques and strategies in the process of organization management, practical approach to marketing and the development of Public Relations in the realities of virtual communication. 